\title{
PET-CT aids in the diagnosis of a choroidal mass with retinal detachment in a patient with history of breast cancer and sarcoidosis
}

\author{
Jonathan M Davison, ${ }^{1,2}$ John H Hotchkiss, ${ }^{1}$ Anthony J Fadell, ${ }^{3}$ Jess A Graham² \\ ${ }^{1}$ Radiology Department, Uniformed Services University of the Health Sciences, Bethesda, Maryland, USA; \\ 2Radiology Department, Madigan Army Medical Center, Tacoma, Washington, USA; \\ ${ }^{3}$ Medicine Department, Madigan Army Medical Center, Tacoma, Washington, USA
}

Correspondence to Dr Jonathan M Davison, jonathan.davison@gmail.com

\section{DESCRIPTION}

The authors report a case of a 47-year-old female with a history of sarcoidosis and early stage breast cancer diagnosed and treated for potential cure 10 years earlier with right mastectomy, who presented with a progressive left visual field defect developing over 2 weeks. Physical examination demonstrated a lobulated choroidal mass with a serous retinal detachment (figure 1). MRI confirmed

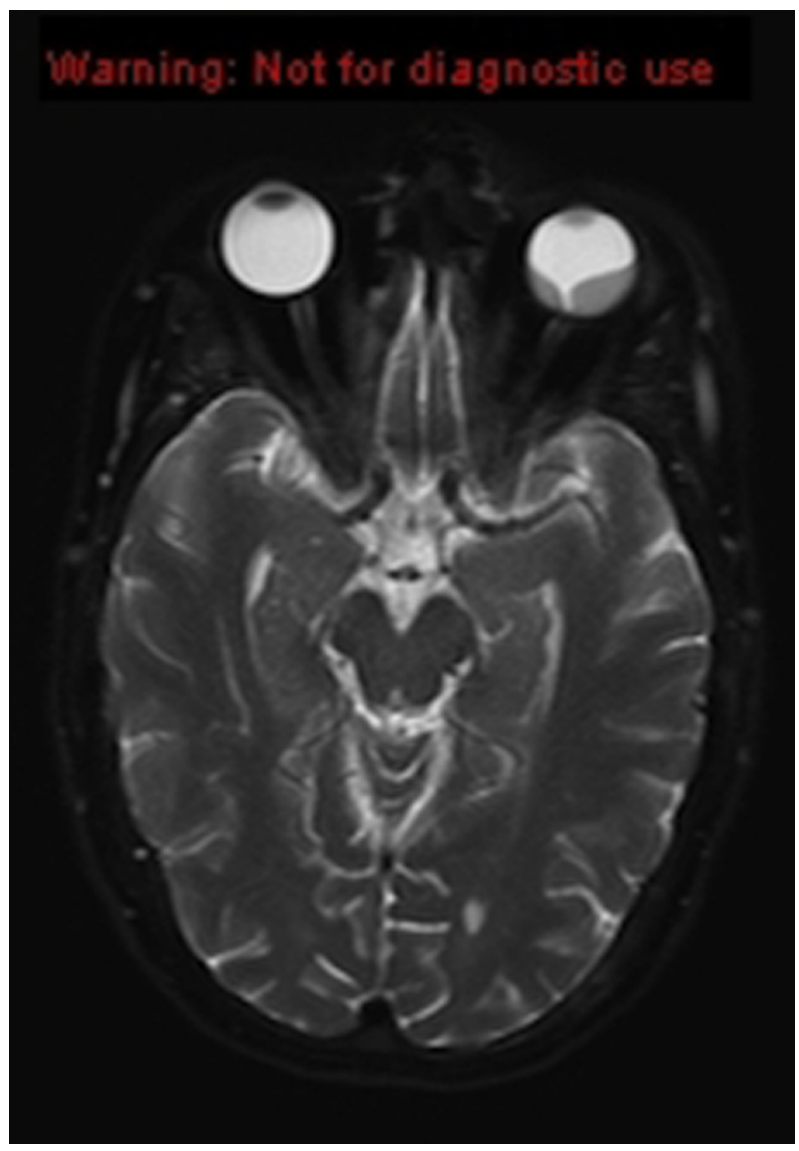

Figure 1 T2 weighted MRI of the orbits demonstrates a V-shaped T2 hypointense signal abnormality pointing toward the optic disc, within the posterior aspect of the left globe, a characteristic MRI finding of a retinal detachment. a left orbital retinal detachment. F-18 flurodeoxyglucose (FDG) positron emission tomography CT (PET-CT) imaging demonstrated hypermetabolism diffusely throughout osseous structures, numerous lymph node stations and the left posterior choroid (figures 2 and 3). No calcified lymph nodes were seen on CT. Retrospective review of the MRI showed very mild enhancement correlating to the hypermetabolic choroid lesion. Biopsy of a hypermetabolic neck lymph node confirmed the presence of metastatic breast cancer. Metastatic carcinoma to the eye is regarded as the most common intraocular malignant neoplasm, which in woman is breast cancer. ${ }^{1}$ Metastatic deposits to the eye can spread to the choroid, optic disc, iris and ciliary body. Choroid tumours are one of the causes of serous retinal detachments, whereby subretinal fluid produces localised exudative or bullous detachments of the retina.

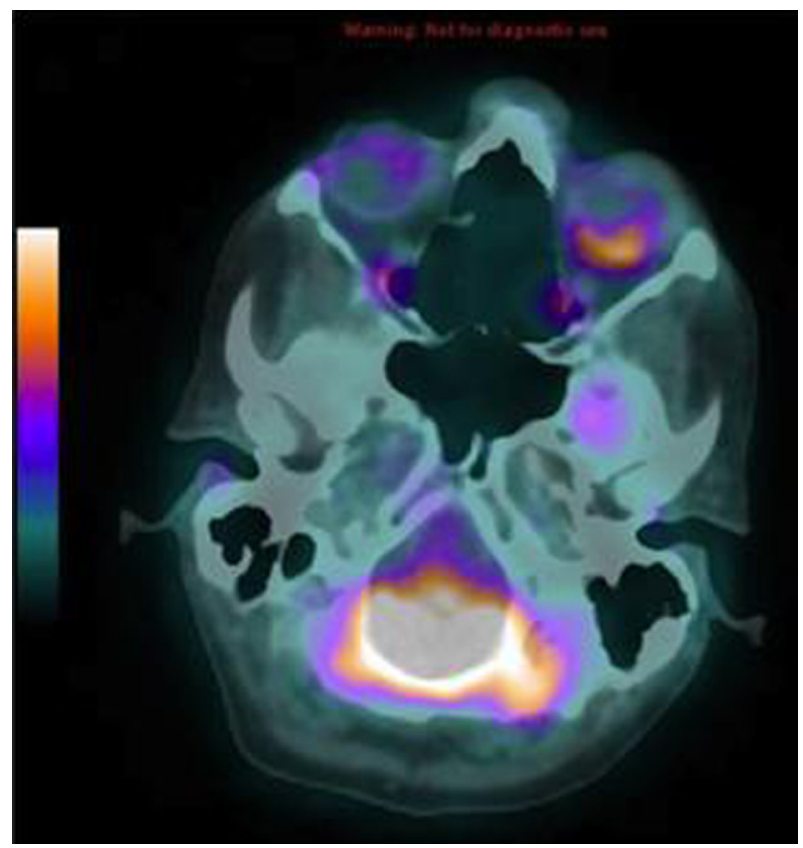

Figure 2 Fusion positron emission tomography CT image demonstrates F-18 flurodeoxyglucose hypermetabolism along the posterior margin of the left globe correlating to signal abnormality on MRI. 


\section{BMJ Case Reports}

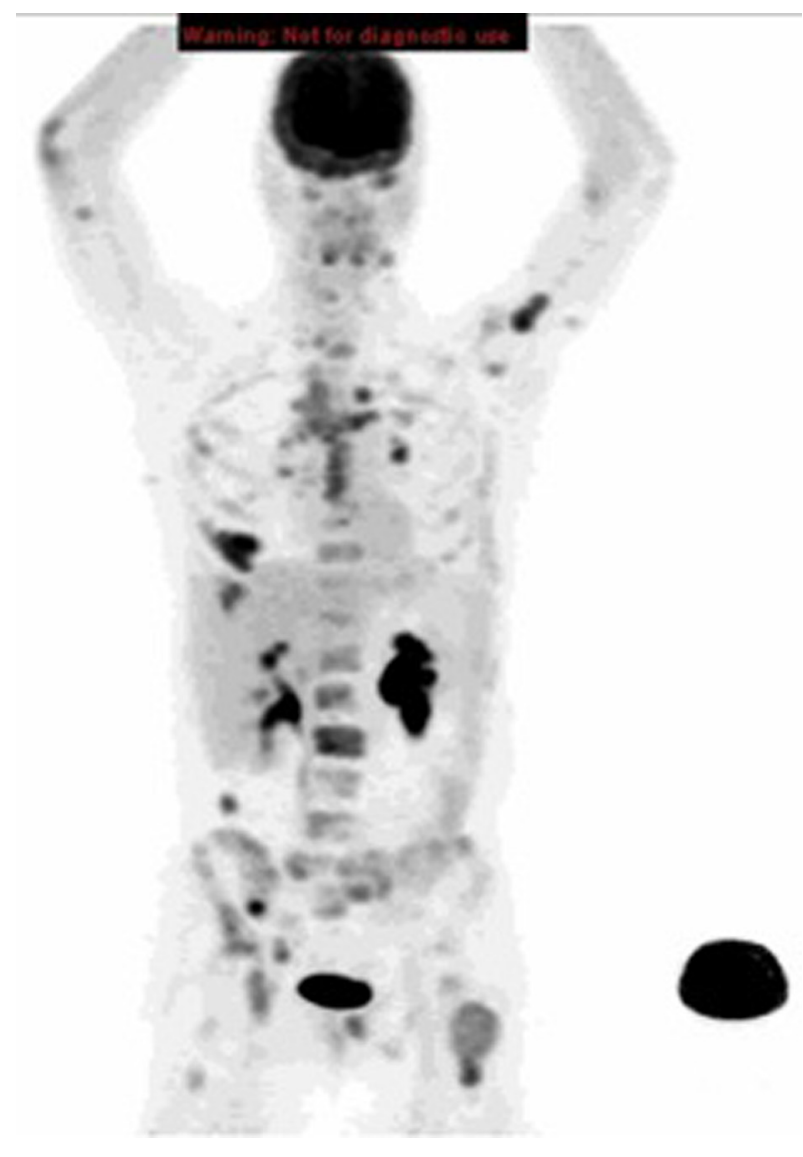

Figure 3 Whole body F-18 flurodeoxyglucose positron emission tomography maximum intensity projection image demonstrates widespread hypermetabolic metastatic lesions throughout the neck, mediastinum, abdomen, as well as the axial and appendicular skeleton.

Malignant retinal detachments are an unusual clinical presentation of metastatic disease. ${ }^{1}$ Retinal detachments are relatively uncommon affecting only 1 in 10000 per year. $^{2}$ Most retinal detachments are rhegmatogenous in origin, a non-malignant condition which occurs when liquid vitreous enters the subretinal space through a retinal defect, creating a dissection plane between the retina and retinal epithelium. ${ }^{2}$ The most common risk factors for rhegmatogenous retinal detachments include aging, cataract surgery, trauma and myopia. ${ }^{1}$ Ocular sarcoid typically causes anterior uveitis, although posterior choroidal granulomas may occur with associated retinal detachments mimicking malignant detachments. ${ }^{1}$ Although sarcoid-related retinal detachment is a consideration in this case, the constellation of findings to include widespread metastatic disease with osseous involvement and lymph node biopsy results of metastatic breast carcinoma strongly favours a malignant aetiology. There is little data on specific MRI or PET-CT findings in ocular sarcoid as the majority of cases are confirmed by a combination of physical examination findings, laboratory abnormalities such as elevated ACE levels, imaging findings such as bilateral hilar lymphadenopathy on chest imaging, and compatible biopsy results. ${ }^{3}$ Several case reports and a small number of studies have confirmed the utility of PET-CT in evaluating ocular metastases. ${ }^{4} 5$ FDG is typically taken up at site of the choroidal metastatic lesion. Differentiating benign from metastatic causes of retinal detachment profoundly alters management in patients with known prior malignancy, as external beam radiation treatment may preserve vision. PET-CT can aid in diagnosis.

\section{Learning points}

- PET-CT is a useful adjunct in the diagnostic imaging armamentarium in patients with suspected ocular metastatic disease.

- Metastatic lesions can cause retinal detachments and should be suspected in the appropriate clinical setting.

\section{Competing interests None.}

Patient consent Obtained.

\section{REFERENCES}

1. Yanoff M, Duker JS. Ophthalmology. Third Edition. St Louis, Missouri: MosbyElsevier 2009.

2. Gariano RF, Kim $\mathrm{CH}$. Evaluation and management of suspected retinal detachment. Am Fam Physician 2004:69:1691-8.

3. Papadia M, Herbort CP, Mochizuki M. Diagnosis of ocular sarcoidosis. Ocul Immunol Inflamm 2010;18:432-41.

4. Nguyen BD, Roarke MC. Choroidal and extraocular muscle metastases from non-small-cell lung carcinoma: F-18 FDG PET/CT imaging. Clin Nucl Med 2008:33:118-21.

5. Finger PT, Chin KJ. [(18)F]Fluorodeoxyglucose positron emission tomography/computed tomography (PET/CT) physiologic imaging of choroidal melanoma: before and after ophthalmic plaque radiation therapy. Int $J$ Radiat Oncol Biol Phys 2011;79:137-42. 


\section{BMJ Case Reports}

This pdf has been created automatically from the final edited text and images.

Copyright 2012 BMJ Publishing Group. All rights reserved. For permission to reuse any of this content visit http://group.bmj.com/group/rights-licensing/permissions.

BMJ Case Report Fellows may re-use this article for personal use and teaching without any further permission.

Please cite this article as follows (you will need to access the article online to obtain the date of publication).

Davison JM, Hotchkiss JH, Fadell AJ, Graham JA. PET-CT aids in the diagnosis of a choroidal mass with retinal detachment in a patient with history of breast cancer and sarcoidosis. BMJ Case Reports 2012;10.1136/bcr.12.2011.5294, Published XXX

Become a Fellow of BMJ Case Reports today and you can:

- Submit as many cases as you like

- Enjoy fast sympathetic peer review and rapid publication of accepted articles

- Access all the published articles

Re-use any of the published material for personal use and teaching without further permission

For information on Institutional Fellowships contact consortiasales@bmjgroup.com

Visit casereports.bmj.com for more articles like this and to become a Fellow

Keep up to date with all published cases by signing up for an alert (all we need is your email address) http://casereports.bmj.com/cgi/alerts/etoc 